\title{
DOSSIÊ DEMOCRACIA, POLÍTICOS E PARTIDOS
}

Apresentação

Paulo Roberto Neves Costa

Como prega Giovanni Sartori (1994), pensar a democracia exige a construção de "argumentos corretos corretamente articulados", dado que seu funcionamento tem como premissa, em geral pouco lembrada, que "idéias erradas sobre a democracia fazem a democracia dar errado".

Não é fácil pensar (nem praticar) corretamente a democracia, ainda mais numa sociedade onde o regime democrático apenas recentemente retomou o seu processo de institucionalização, como é o caso brasileiro.

A título de reflexão, podemos nos valer de algumas singelas idéias de um punhado de autores do século passado para comentar certos fatos e comportamentos recorrentes que fazem parte do cotidiano nacional a fim de restaurar a "clareza mental" que o mesmo Sartori associa à democracia (sem a ingenuidade de acreditar que os problemas do funcionamento concreto e da análise teórica da democracia têm como causa exclusiva a obscuridade dos princípios e a confusão das idéias).

Ao olharmos para a "experiência democrática" no Brasil hoje, observamos, entre outros problemas, a existência de uma tensão não resolvida entre democracia e discurso técnico, tensão esta que aparece - quer se tome a atitude, quer se tome as idéias de jornalistas, entidades, políticos, analistas e "cidadãos" — na prática recorrente da desqualificação (técnica, política ou moral) dos antagonistas - quando não simplesmente sua satanização.

Como se sabe, Weber (para quem a desqualificação dos adversários é o mais vergonhoso dos excessos que se pode cometer na política), considerava como uma característica fundamental do Estado Moderno e um ingrediente imprescindível da democracia a existência de uma administração pública fundada na competência. Este nem de longe parece ser o caso brasileiro, para dizer o menos.
Mas Weber tinha outra preocupação "clássica": apontava como ameaça à democracia não só a burocracia alçada à política, mas principalmente a despolitização da política, além da ausência de garantias para os "direitos do homem".

A competência técnica é requisito central no processo de administração de sociedades complexas. Contudo, a restrição da escolha que caracteriza o ato de governar numa função derivada das assim chamadas "condições objetivas" é deletéria ao processo de consolidação democrática em mais de um sentido. Porque exige que se expurgue da política democrática um de seus princípios fundamentais: o enfrentamento entre propostas, a pluralidade de interesses, o debate dos contrários e a responsabilidade das decisões. E também porque essa compreensão restrita da ação do governante (a "utopia possível") apaga do horizonte o fato básico e inescapável segundo o qual, nas decisões político-administrativas, alguns interesses possam vir a ser atendidos, total ou parcialmente, e outros não, cabendo aos decisores fazer uma escolha, que é, acima de tudo, política.

Tomando o mesmo problema - o da relação entre democracia e administração — por outro ângulo, seria preciso considerar aquilo que Schumpeter (1961) chama de a "natureza humana na política", ou seja, a dificuldade dos "cidadãos" comuns para lidar com problemas que vão além do seu cotidiano pessoal e profissional. Como resposta a essa dificuldade, Schumpeter, assim com Weber, insistem na necessidade de institucionalizar regras e procedimentos para selecionar líderes políticos e gerar programas de governo a fim de definir diretrizes para a máquina burocrática estatal e evitar que agentes inescrupulosos ou despreparados cheguem ao poder. Só isso permite realizar a democracia e consolidá-la junto à sociedade.

Sem ingenuidade, Weber e Schumpeter ensinam que a democracia é, efetivamente, uma forma 
de escolha dos governantes, forma essa que traz consigo toda uma série de "dificuldades práticas": a manipulação do eleitorado, a apatia política, a falta de escrúpulos - em especial do Governo na condução das campanhas, as ideologias etc. Mas acrescentam que a democracia deveria ao menos resguardar alguns princípios e valores coletivamente discutidos e minimamente partilhados, a serem institucionalizados pelas normas e convenções.

No Brasil, a exclusão econômica está longe de ser meramente econômica, pois torna difícil que grande parte da população reconheça minimamente a necessidade de respeitar as regras políticas e morais da sociedade. Daí que a desigualdade econômica não cause apenas fome e pobreza, mas reduza bastante a possibilidade da participação e adesão por parte dos "desfavorecidos" na construção e sustentação do arranjo político-institucional e dos valores que lhe são caros. Dessa forma, o que talvez seja tão ou mais pernicioso do que a desigualdade social, o desemprego, a desarticulação da indústria nacional ou a desnacionalização da economia, é a não institucionalização da democracia, seja enquanto conjunto de regras formais estabelecidas para a disputa entre propostas políticas, seja enquanto cultura política, isto é, comportamentos e valores éticos fundados sobretudo na convicção e em convenções, e não somente na letra das leis.

A legitimação através do voto para os mandatos públicos democraticamente constituídos não autoriza o abandono do debate acerca da necessidade de construção de espaços públicos de manifestações de oposição, de reivindicação, de denúncia e de crítica. Caso contrário, estaríamos reforçando o caráter delegativo que Guilhermo O’Donnell (1991) detectou na nossa democracia.

A relevância dos artigos reunidos neste Dossiê Democracia, Políticos e Partidos para o aprofundamento dessa discussão é completa.

Francisco Pereira de Farias discute a compatibilidade entre clientelismo e democracia no Brasil, a partir de um caso empírico, e constata que esse tipo de relação, fundada na utilização privada de bens públicos com fins político-eleitorais, corresponde à própria estrutura da sociedade capitalista no Brasil. Farias destaca a existência de relações pré-capitalistas e o caráter acelerado da implantação do capitalismo no campo como condicionantes da ação dos partidos, da organização das classes populares e da formação da cidadania política e da democracia em nosso país. O autor conclui que, nestas condições, o clientelismo seria algo constitutivo, "normal" e até "funcional" para a política brasileira.

Luzia Helena Herrmann de Oliveira faz um balanço das principais interpretações do processo de retomada das instituições democráticas no Brasil, em especial dos partidos políticos. Seu percurso pela literatura, além de ilustrativo, tenta mostrar que a comparação com as experiências democráticas recentes, mais especificamente as do sul da Europa, é o meio mais interessante para a construção de um instrumental teórico produtivo sobre o assunto. Além disso, faz uma discussão teórica acerca da consolidação da democracia no Brasil, concluindo que a comparação com as experiências de retomada e consolidação da democracia em países do leste europeu e da América Latina são mais sugestivas do que a recorrência a modelos clássicos como a poliarquia de Dahl.

Simone Diniz investiga a intensa migração partidária dos políticos de uma legenda a outra, migração essa que não pode ser explicada pela simples ausência de algum tipo de coibição legal, mas que deve ser vista a partir do cálculo em relação ao ganho que a troca implicaria. A tese fundamenta-se numa alentada pesquisa empírica e atualizada discussão bibliográfica. Para a autora, a legislação partidária não "causa" as migrações, mas cria "exigências" — o prazo pré-estabelecido para deferimento da filiação partidária - e gera "incentivos" - o tempo maior de propaganda gratuita a que os partidos têm direito - aos parlamentares que buscam mudar para uma agremiação que lhe ofereça maiores vantagens.

Sandro Anselmo Coelho compara as experiências partidárias da Democracia Cristã no Brasil (de 1946 a 1964) e no Chile (de 1964 a 1970), tendo por referência a sua articulação com o populismo, entendido como forma particular de relação entre as massas populares e a política no contexto de constituição do capitalismo industrial. Conclui que as propostas da democracia cristã, que, a princípio, seriam voltadas para a constituição de uma nova ordem social, tenderam a privilegiar mais a crítica ao socialismo do que ao próprio capitalismo.

A preocupação com as instituições democráticas não deve negligenciar a questão dos valores e princípios democráticos, já que é difícil tratar 
da democracia sem enfrentar esse problema. Daí a pertinência do trabalho de Klaus Frey, que traz, para o debate acerca da consolidação e da institucionalização da democracia no Brasil, uma análise bastante sugestiva de um clássico da teoria da democracia. Encontraríamos em Tocqueville, segundo Frey, elementos para tratarmos da institucionalização de processos como a descentralização do poder e a conscientização política.

Em suma, como nos sugerem os pensadores políticos deliberadamente mencionados na parte inicial desta apresentação - Sartori, Weber,
Schumpeter e O'Donnell, para não falar de Norberto Bobbio (1986) e de sua denúncia das "promessas não cumpridas" pela democracia e como mostram os artigos do Dossiê que apresentamos, a realidade da democracia implementada no Brasil, do passado e do presente, não passaria sequer pelo crivo da crítica liberal contemporânea, o que dizer de outras perspectivas mais críticas.

Os editores da Revista de Sociologia e Política esperam apresentar assim aos seus leitores mais uma contribuição para vincular a pesquisa sociológica e o debate político sobre as grandes questões da atualidade.

Paulo Roberto Neves Costa (paulornc@humanas.ufpr.br) é doutorando em Ciências Sociais na Universidade Estadual de Campinas (UNICAMP) e Professor de Ciência Política na Universidade Federal do Paraná (UFPR).

\section{REFERÊNCIAS BIBLIOGRÁFICAS}

BOBBIO, N. 1986. O futuro da democracia. Rio de Janeiro : Paz e Terra.

O'DONNELL, G. 1991. Democracia delegativa? Novos Estudos CEBRAP, São Paulo, n. 31, p. 25-40.

SARTORI, G. 1994. A teoria da democracia revisitada. São Paulo : Ática.
SCHUMPETER, J. A. 1961. Capitalismo, socialismo e democracia. Rio de Janeiro : Fundo de Cultura.

WEBER, M. 1985. Parlamentarismo e governo numa Alemanha reconstruida. São Paulo: Abril Cultural.

WEBER, M. 1999. Economia e sociedade. Vol II. Brasília : Edunb. 